\title{
Using problem-based learning in college: Mastery concepts subject statistical research and motivation
}

\author{
Ediansyah Ediansyah $^{1}$, Dwi Agus Kurniawan², Rahmat Perdana ${ }^{3}$, Salamah Salamah ${ }^{4}$ \\ ${ }^{1,4}$ Department of Elementarry Teaching and Education, Bengklu Islamic Institute, Indonesia \\ ${ }^{2,3}$ Department of Physics Education, Universitas Jambi, Indonesia
}

\begin{tabular}{l} 
Article Info \\
\hline Article history: \\
Received Jun 22, 2019 \\
Revised Jul 20, 2019 \\
Accepted Aug 29, 2019 \\
\hline Keywords: \\
Learning motivation \\
Problem-based learning \\
The ability of research \\
statistical concept mastery
\end{tabular}

\section{Corresponding Author:}

Dwi Agus Kurniawan,

Department of Physics Education

Universitas Jambi,

Lintas Jambi-Muaro Bulian Street KM. 15, 36361, Jambi, Indonesia

Email: dwiagus.k@unja.ac.id

\begin{abstract}
Based on the problems obtained, the ability of students to subjects of research statistics is still categorized as low until this causes them to be weak in completing their final assignments. Therefore, the researchers investigated how students' mastery of the research statistical concepts and their learning motivation using learning innovations, one of which was Problem Based Learning (PBL). This research was conducted at the Islamic Education School (PGMI) Islamic State Teacher Education Institute (IAIN) Bengkulu used was semester $8^{\text {th }}$ students for a sample. The research method was quantitative with a sample of 145 . The research instrument was using a motivation questionnaire and multiple choice questions. The results will then be analyzed using simple regression analysis which will be presented in the form of a data table.
\end{abstract}

Copyright () 2019 Institute of Advanced Engineering and Science. All rights reserved.

\section{INTRODUCTION}

Educators play important role in education of the Republic of Indonesia Law number 20 of 2003, Educators are qualified teaching staff as teachers, lecturers, counselors, tutors, widyaiswara, tutors, instructors, facilitators and other name with their own specialty, and participating in education administration. In higher education, educators are lecturer [1]. Lecturers are professionals who are tasked with planning and implementing the learning process, assessing the results of learning, guiding and training, and conducting research and community service. This fact shows that major developments taking place in the field of education follow up on global progress and trends in teaching approaches [2]. The successful implementation of learning strategy depends of a lecturer in teaching students to use methods, techniques, and learning strategies to invite students receive learning material with fun. [3] States that each student has different abilities and characteristics so the teacher have to do variation in teaching. Especially for students of the Madrasah Ibtidaiyah Teacher Education educators who trigger student in critical thinking and concepts understanding. Therefore, today students only focused on theory without developing their mind.

Seeing the important role of lecturers in training students' thinking skills, a strategy is needed in static learning. Statistics are a way to learn about how students are confronted with building and interacting with statistical models, and integrated with data samples, probabilistic models, contexts and conclusions enhanced by technology [4]. This statistics course has an important role in life, according to [5] the statistics section is a necessity in solving contextual problems that are relevant to real life. However, in reality, at IAIN Bengkulu it is still difficult to understand the concept of statistics.

Seeing the students in statistical concepts can be seen in processing and analyzing data such as descriptive and inferential data. Descriptive statistics report trends and variations in data centers so they can 
provide information that can facilitate understanding of the results of the data obtained [6]. According to [7] inferential statistics aims to answer questions in a study, where researchers analyse data from research samples to conclude unknown populations and can assess whether there are differences in groups or relationships between variables whether far greater or less than what is expected in total. Based on an explanation of understanding statistical concepts, the importance of students to be able to master this subject is to facilitate the completion of the final project. The final project is a scientific work created by students as a prerequisite for achieving an academic degree. Based on the Regulation of the Minister of Research, Technology and Higher Education of the Republic of Indonesia Number 44 of 2015 concerning National Standards for Higher Education Article 46 Paragraphs 1, 2, and 3.

The success rate of teaching staff in teaching seen from the success of their students, so it is said that great educators are educators who can inspire students [8]. According to [9]; [10] Argues that teachers must do varied learning in order to improve students' abilities. PBL is one of those lessons. PBL is a learning and teaching strategy designed to involve students in solving problems [11, 12]. Problem-solving skills are seen from the ability of students to investigate a problem and find ways to solve a given problem [13, 14]. Meanwhile, cooperation is an important component in solving a problem [15]. Therefore the PBl model has a good impact on learning.

Motivation According to [16], in general, motivation means something that encourages to do or act. Motivation can be interpreted as the strength (energy) of a person which can give rise to a level of persistence and enthusiasm in carrying out an activity, both from within the individual (intrinsic motivation) [16]. For example, students have their own willingness to learn physics, be able and concentrate while studying physics [16]. And from outside the individual (extrinsic motivation) [16]. Like getting a prize and getting good grades [16]. Furthermore, according to [17], motivation is a change in energy in a person (person) who is characterized by the emergence of feelings and reactions to achieve goals. The students who have a negative attitude towards physics have a lack of motivation for class engagement, and also students who have positive attitudes towards physics have motivation for class engagement [17]. In motivation there are so many kinds, one of which is motivation in learning. Motivation to learn is a process that encourages learning, direction, and persistence of behavior, motivated behavior is behavior that is full of energy [16]. In order to increase motivation, teachers can make various studies in the environment so that their motivation towards their class can attract students' attention [18]. Furthermore, according to [17] motivation to learn is a psychological aspect that experiences development, meaning that it is affected by physiological conditions and psychological maturity of students. According to [16] he classified the indicators of learning motivation as follows: (1) the existence of desires and desires succeeded. (2) there is encouragement and need for learning. (3) future hopes and aspirations. (4) there is appreciation in learning. (5) there are interesting activities in learning. (6) the existence of a conducive learning environment that allows students to learn well.

Learning innovation with PBL, students can have the ability to think critically [19]. Also, one of the goals of education, especially in higher education institutions, is to equip students in achieving learning. Although the term learning innovation has a broad definition, in the context of higher education, it generally refers to students who are responsible, directing and regulating their learning processes [20].

\section{RESEARCH METHOD}

This research uses descriptive research method. "Descriptive research is research that uses words and numbers in presenting profiles, classifying types, and outlining steps to answer questions such as who, when, where, and how" [21]. The descriptive approach is used because this research will look at the extent to which students the concept of statistical in the thesis.

Next is to determine student motivation in learning statistical research. Then see the influence PBL in understanding students' statistical concepts in research and motivation to learn. The population in this study were eight-semester students who had taken statistical studies at IAIN Bengkulu, the sample was 145 semester eight. Total sampling is a sampling technique used in this study. Total sampling is the overall sampling technique from the population [22]. Total sampling was chosen as the determination of the sample because researchers want to know the overall results of the existing population. Data collection in this study used a questionnaire and mutiple-choice test instrument. A questionnaire was used in the survey design that studied it entirely and returned it to researchers [7, 23].

Data collection in this study also used interviews. Qualitative interviews occur when researchers ask one or more general participants, open questions and record their answers [7]. Interviews are used as data collection tools so that researchers are able to deepen the constraints of students in statistics in the final project. The flow of research in collecting research data is shown in Figure 1. 


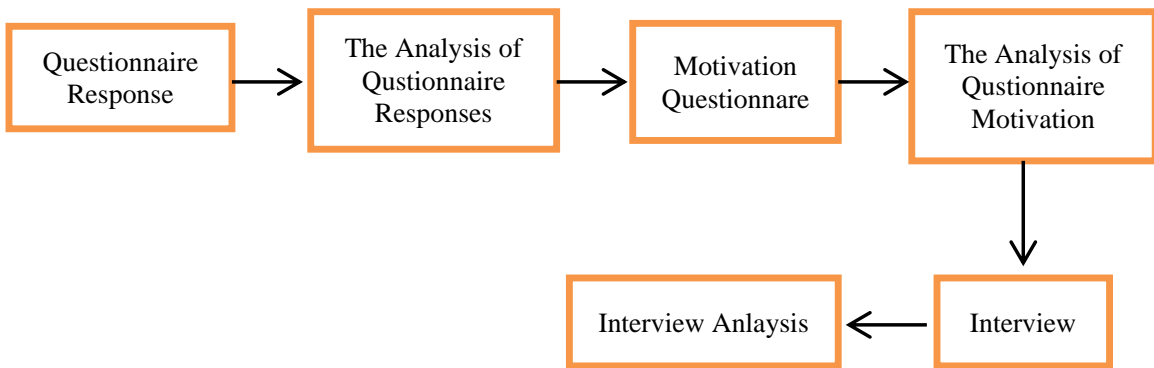

Figure 1. Procedure of data collection

Questionnaire is a technique to collect data where participants or respondents later after being filled in with complete return to the researcher [6]. The questionnaire used included the learning motivation questionnaire and the student response questionnaire. Table 1 illustrates the range of values for the motivation questionnaire and table 2 for the response questionnaire, in which there are four categories, which are very good, good, bad, and bad.

Tabel 1. Categorizes the value range of the learning motivation questionnaire

\begin{tabular}{cc}
\hline Kategori & Rentang Skor \\
\hline Very Good & $74.8-92.0$ \\
Good & $57.6-74.7$ \\
Poor & $40.3-57.5$ \\
Bad & $23.0-40.2$ \\
\hline
\end{tabular}

Table 2. Categorizes of the range of response questionnaire

\begin{tabular}{cc}
\hline Category & Interval \\
\hline Very Good & $58.6-72.0$ \\
Good & $45.1-58.5$ \\
Poor & $31.6-45.0$ \\
Bad & $18.0-31.5$ \\
\hline
\end{tabular}

Quantitative data were analyzed using SPSS. Descriptive data used include mode, median, mean, and frequency. Furthermore, researchers give multiple choice questions to students Teacher Education of Madrasah Ibtidaiyah $8^{\text {th }}$ semester with four answer options option. MCQs done with the intention for see the mastery level of statistical concepts $8^{\text {th }}$ semester student see in the Table 3 .

Table 3. Categorizes range of strengthen concept MCQs

\begin{tabular}{cc}
\hline Category & Interval \\
\hline Very Good & $75.1-100.0$ \\
Good & $50.1-75.0$ \\
Poor & $25.1-50.0$ \\
Bad & $0.0-25.0$ \\
\hline
\end{tabular}

MCQs analyzed for descriptive statistics. Then the researcher continued collecting data using a structured interview instrument. Interviews were conducted for $8^{\text {th }}$ semester students. Interviews are used as quantitative data reinforcement. Then the researcher conducted a document analysis in the form of a learning implementation plan to support the questionnaire data, multiple choice questions, and the results of interviews.

\section{RESULTS AND ANALYSIS}

The renewal of this research is if students have the ability to apply concepts in research methods courses, with students understanding about the concepts that exist in this research method will make it easier for students to complete their final assignments (thesis). 


\subsection{Ability of the concept of research statistics}

The following are the results of the ability to students' statistics reearch. The results are obtained using a MCQs in Table 4.

Table 4. Results of ability of the concept of research statistics

\begin{tabular}{|c|c|c|c|c|c|c|c|}
\hline & \multicolumn{3}{|c|}{ Male } & & \multicolumn{3}{|c|}{ Female } \\
\hline & Category & Frequency & $\%$ & & Category & Frequency & $\%$ \\
\hline & Very Good & 3 & 9 & & Very Good & 10 & 9 \\
\hline Students of 8 & Good & 10 & 29 & Students of 8 & Good & 28 & 25 \\
\hline \multirow[t]{3}{*}{ Semester } & Poor & 16 & 46 & Semester & Poor & 43 & 39 \\
\hline & $\mathrm{Bad}$ & 6 & 17 & & $\mathrm{Bad}$ & 29 & 26 \\
\hline & Total & 35 & 100 & & & 110 & 100 \\
\hline
\end{tabular}

From Table 4, the results of research students' statistic is $17 \%$ were in the bad category, $46 \%$ were poor, $29 \%$ were good and $9 \%$ were excellent. As for the female students have percentage $26 \%$ is poor, $39 \%$ in the unfavorable category, $25 \%$ is good category and $9 \%$ is excellent category.

Based on the data obtained the mastery of the research statistics of the Madrasah Ibtidaiyah Teacher Education (PGMI) students is good category, this is seen when students have the ability to work on assignments in accordance with the material and subject matter summarized in the research statistics course such as the use of manual calculations or use of applications that can help in mastering research statistics. And students understand material related to statistics such as understanding the meaning of using descriptive statistics and inferential statistics in statistical subjects research. Research statistical material is easy to understand with the help of better statistical understanding, such as understanding the calculation of mean, mode, frequency used in descriptive statistics (Student interview, November 2018).

In statistics, we distinguish between the most commonly used statistical methods; descriptive and inferential [24]. Descriptive statistics arise naturally in this class because students know about collecting data and describing populations. Sample statistics, median, variance, sd a clear estimator of their population, Mean, Median, Variation, Standard Deviation (SD) [25, 26] states statistics are about the most important things in human affairs. This is about our understanding of the world around us and how that understanding affects the life we live.

Over the years there has been strong anecdotal evidence that students at universities develop antipathy towards statistics and, usually, students at all levels are less interested in learning when taking introductory statistics courses. Over the past decade there have been significant concerns expressed about the future of statistics [27]. Not all statistical service courses are at the introductory level, but they often stand alone, that is, they are not part of a progressive sequence in statistics [28].

\subsection{Students learning motivation}

The results obtained in Table 5. The percentage of male student learning outcomes is $0 \%$ as a bad category, $29 \%$ is bad, $57 \%$ is good and $14 \%$ is very good. Whereas for female students it has a percentage of $0 \%$ in the bad category, $30 \%$ is in the bad category, $55 \%$ is good and $15 \%$ is very good.

Table 5. Student motivation questionnaire results based on gender

\begin{tabular}{clllllll}
\hline & \multicolumn{3}{c}{ Male } & \multicolumn{3}{c}{ Female } \\
& Category & Frequency & $\%$ & & Category & Frekuenqy & $\%$ \\
\hline Students of 8 & Very Good & 5 & 14 & Students of 8 & Very Good & 17 & 15 \\
Semester & Good & 20 & 57 & Semester & Good & 60 & 55 \\
& Poor & 10 & 29 & & Poor & 33 & 30 \\
& Bad & 0 & 0 & & Bad & 0 & 0 \\
Total & & 35 & 100 & Total & & 110 & 100 \\
\hline
\end{tabular}

Based on the data obtained, for the motivation of students in good category, this is seen when students work on assignments individually, do not continuously depend on others, and look for additional information about the statistical concept of research in increasing knowledge.

Previous reserachers [29, 30] said that cooperative learning groups can offer potentially valuable learning opportunities, but it should be realized that only adopting one of the structures of cooperative learning does not necessarily promote deep involvement. Like assignments and subjects must be quite challenging without being too difficult. Discussing, implementing, and interpreting may be more tasks that mean to work together rather than easier tasks to define and explain concepts. Another researcher [31] said 
The Cooperative Learning Strategy (CLS) is a series of techniques and strategies aimed at institutionalizing collaboration and teamwork among practitioners to improve the efficiency of training and learning. There have been remarkable changes from teacher-centered to setting up learner-centered language learning through which teachers provide more space for language learners to be responsible for their own learning in individual perspectives and also responsible for learning their colleagues in a collaborative perspective and teamwork. In this way students take on the role of facilitators themselves rather than their teachers [32-34].

\subsection{Response of students to the use of problem based learning (PBL)}

Looking at the results of pedagogical competencies viewed by age, we find that the older the age of a teacher, the less pedagogical competencies presented can be seen in Table 6. From the table, it can be seen that from the 145 majority students are female students. The percentage of results is $66 \%$ of male students are good while female students have a percentage of $55 \%$ is a good category.

Table 6. Student response questionnaire results by gender

\begin{tabular}{clcccccc}
\hline & \multicolumn{3}{c}{ Table 6. Student response questionnaire results by gender } \\
& Category & Frequency & $\%$ & & \multicolumn{3}{c}{ Female } \\
\hline Students of 8 & Very Good & 7 & 20 & Students of 8 & Very Good & Frequency & $\%$ \\
Semester & Good & 23 & 66 & Semester & Good & 60 & 27 \\
& Poor & 5 & 14 & & Poor & 20 & 18 \\
Total & Bad & 0 & 0 & & Bad & 0 & 0 \\
& & 35 & 100 & & Total & 110 & 100 \\
\hline
\end{tabular}

Based on the data obtained the response of the students of Madrasah Ibtidaiyah Teacher Education using the PBL model was included in the good category, because the model with giving problems early helping students respond to active thinking and lectures can run smoothly so that the material provided by lecturers is easy to understand by students and students are interested in attending lectures using PBL because the research statistics subject given by the lecturer is appropriate and well implemented so that students easily understand the material and concepts given. From the interviews, the use of the PBL model in the research statistics course is suitable because the statistics course requires more concentration in order to obtain good learning outcomes and able to create lecture synchronization between lecturers and students, so that the material and concepts are well understood. In addition, research statistics courses use the model PBL is very useful for completing thesis thesiss because my research uses inferential statistics. And the method that I use is the experimental method [35].

Based on the data obtained the response used the PBL model was included in the unfavorable category, because when the material was given by lecturers was limited problems only, the lecturer does not explain in detail the material and concepts in the research statistics course, so there is a lack of synchronization between the material provided with the PBL model used by lecturers and students not interested in taking lectures using the model PBL because in order to understand the statistical subject obtained prior knowledge of statistical concepts. The results of the interviews were obtained by students not understanding the delivery of material through the used of PBL models used in lectures, and I was confused by statistical research. I am inclined to qualitative research without using scores and quantitative/statistical calculations. Although basically the research statistics course helps with my thesis, thesis (Student interview, November 2018).

According to [32] the curriculum must be the same in students' conceptions, because in order to create variations and help students to improve their knowledge of statistics. In developing the statistical concepts of students, the widest and most inclusive, the curriculum is encouraged to realize students' perceptions of their own place in the world, and critical assessment of how statistics can help them. [38, 39] say that events in mathematics learning can have effects in statistical learning at the University. This development is on going. The results of this study are an illustration that we can only capture the moment in sustainable development of students thinking skill.

\subsection{Effect of problem based learning on mastery research statistics and student motivation}

Beside quantitative data, qualitative data from interviews were also collected. As opinion by 8th semester students. To answer the fourth research question about the constraints of student learning motivation on statistical subjects for thesis, the following interviews were obtained: The first point is its implementation in student lecture activities:

a. Implementation is that students can learn when lectures take place in classes in research statistics. The material is in the form of giving problems related to research statistics. Then students who solve the 
problems given are in accordance with the objectives of the lecture using the problem based learning (PBL) model. (Student interview, 2019).

b. Lectures held in class and outside the classroom can provide student motivation. Sometimes students prefer to study outside the classroom than in class because students assume that learning outside the classroom is more concentrated than in the classroom, because other students can interfere with the concentration of learning so students are less motivated in completing class assignments in class. Subjects of research statistics. (Student interview, 2019).

c. When lecturers provide material and assignments in research statistics courses using the problem based learning (PBL) model that gives problems, then I am motivated to do it myself the task is not to see the assignments of other students and me. Try doing it yourself without the help of others. However, when I had difficulty understanding the assignment after trying it myself, I also did not understand it, I asked and asked for opinions from people who were more expert and more understanding to give information to me. (Student interview, 2019).

d. Research statistics are important subjects. Therefore students who like the research statistics course think the research statistics course is very helpful in conducting research related to the final thesis of students in the next semester. For students who don't like research statistics, they assume that the research statistics course is a subject that is less fun and difficult to understand because it deals with formulas and mathematics. (Student interview, 2019).

These comments indicate that students have implemented knowledge about research statistics courses using the problem based learning (PBL) model and have different learning motivation. The next point of the interview question is about the obstacles faced by students in implementing research statistics courses:

a. Constraints found in lectures on research statistics are lecture material which is considered difficult to understand for some students who contract research statistics courses. (Student interview, 2019).

b. Constraints on learning devices and learning models used by lecturers when the lecture takes place. Because students are not used to learning by giving problems to solve themselves. This makes it difficult for some students to understand lecture material well because it is hampered by the unfamiliarity of students in solving the problems given. (Student interview, 2019).

c. The problem is that not all students who contract research statistics courses understand the concept of research statistics well. This was seen when the lecture took place, students were motivated to do the assignments given by the lecturers. Whereas students who lack and do not like the subject of research statistics will look at the tasks performed by other students. (Student interview, 2019).

d. Constraints on each student are different, some are limited by detailed information and explanations about the material in the research statistics course. Information is obtained from books, articles, libraries, and experts in research statistics. It can be seen from students who do have high learning motivation, they will always look for information from various sources. But this is reversed, if students have low learning motivation to find less information. (Student interview, 2019).

The comment shows that there are still many obstacles faced by students in the implementation of the research statistics subject in lecture activities. These constraints come from students, lecturers and supporting facilities and infrastructure. To answer the fourth research question about the effect of problem based learning on mastery of research statistics and student learning motivation, the hypothesis test is a regression test. Table 7 shows the results of test analysis regression to address the effect of problem based learning to the ability of mastering statistical concept study.

Tabel 7. Effect of PBL to the ability to master statistical concepts empirically

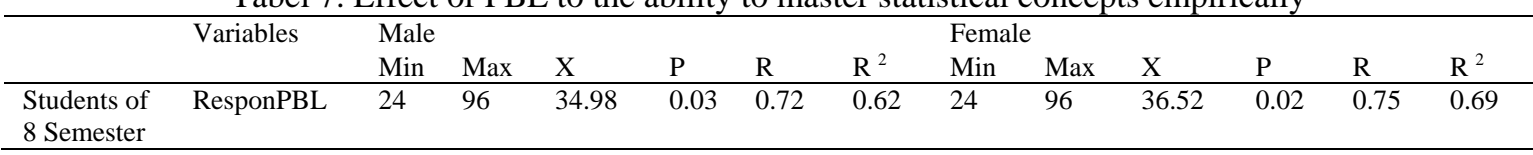

Based on Table 7, the influence of PBL on mastery of research statistical concepts there is an influence between PBL and mastery of concepts, because the significance value is $<0.05$. The contribution of the influence of PBL to the mastery of concepts in the students of type is $68 \%$. Another factor that contributed to the influence of PBL on mastery of concepts in students was $32 \%$. The contribution of the influence of PBL to the mastery of the concept in the eighth semester students of the type is $70 \%$. Another factor that contributed to the influence of PBL on mastery of concepts in 8th semester students was as much as $30 \%$. As for other factors that influence PBL on the mastery of concepts in students, namely the lack of collaboration within groups. In cooperative group work, each team member is responsible not only for 
[5]. Reston, E., and Krishna, S., "Statistics education research in Malaysia and the Philippines: A comparative analysis," International Association for Statistical Education, vol. 13(2), pp. 218-231, https://iaseweb.org/documents/SERJ/SERJ13(2)_Reston.pdf, 2014.

[6]. Creswell, J.W., "Research design qualitative, quantitative, and mixed method aproach," Singapore : SAGE Publications Asia-Pacific, 2009.

[7]. Creswell, J., W., "Educational research quantitative and qualitative," Lincoln : University of Nebraska, 2012.

[8]. Sofanudin, A., and Rokhman, F., "Quality-oriented management of educational innovation at Madrasah Ibtidaiyah," Journal of Education and Practice, vol. 7(27), pp. 176-180, https://files.eric.ed.gov/fulltext/EJ1115847.pdf, 2016.

[9]. Kunnari, I., and Ilomäki, L., "Reframing teachers' work for educational innovation," Innovations in Education and Teaching International, vol. 53(2), pp. 167-178, Retrieved from: https://doi.org/10.1080/14703297.2014.978351, 2016

[10]. Rabgay, T., "The effect of using cooperative learning method on tenth grade students' learning achievement and attitude towards biology," International Journal of Instruction, vol. 11(2), pp. 265-280, https://doi.org/10.12973/iji.2018.11218a, 2018.

[11]. Vandenhouten, C., Groessl, J., Levintova, E., "How do you use problem-based learning to improve interdisciplinary thinking?," New Directions for Teaching and Learning, 2017(151), pp. 117-133, Retrieved from: https://doi.org/10.1002/tl.20252, 2017.

[12]. Rusmansyah, R., Yuanita, L., Ibrahim, M., Isnawati, I., Prahani, B.K., "Innovative chemistry learning model: Improving the critical thinking skill and self-efficacy of pre-service chemistry teachers," Journal of Technology and Science Education, vol. 9(1), pp. 59-76, Retrieved from; http://dx.doi.org/10.3926/jotse.555, 2019.

[13]. Gillette, C.M., "Consideration of problem-based learning in athletic training education," Athletic Training Education Journal, vol. 12(3), pp. 195-201, Retrieved from: https://doi.org/10.4085/1203195, 2017.

[14]. Zhong, N., Yingxu Wang, Y., Chiew, V., "In the cognitive process of solving human problems,"Penelitian Sistem Kognitif, vol. 11, pp. 81-92, Retrieved from: http://doi.org/10.1016/j.cogsys.2008.08.003, 2010.

[15]. Winarno, Sri., Muthu, KS, Ling, L.S., "Direct problem-based learning (DPBL): A framework for integrating direct instruction and problem-based learning approach," International Education Studies, vol. 12, pp. 1-8, Retrieved from: https://doi.org/10.5539/ies.v11n1p119, 2018.

[16]. Higgins, E. T and Kruglanski, A, W., "Motivational science social and personality perspectives," USA : Taylor \& Francis, 2000.

[17]. Guido, R. M., "Attitude and motivation towards learning physics," International Journal of Engineering Research \& Technology, pp. 2087-2094, 2013.

[18]. Tugun, Vaspi, "Impacts and opinions on the technology self-sufficiency of the students who are coding education in the flipped classroom adapted to the ARCS motivation model," TEM Journal, vol. 7(2), pp.366-371, Retrieved from: https://dx.doi.org/10.18421/TEM72-18, 2018.

[19]. Khoroshikh, P.P., Sergievich, A.A., Platonova, R.I., "Development of students' critical thinking by active and interactive training methods," TEM Journal, vol. 7(4), pp.787-790, https://dx.doi.org/10.18421/TEM74-14, 2018

[20]. Kostadinova, P, S., "Training of social management specialists for participation in social innovation teams," TEM Journal, 7(2), pp. 348-354, Retrieved from: https://dx.doi.org/10.18421/TEM72-16, 2018.

[21]. Neuman. LW, "Basics of social research: Qualitative \& quantitative approaches," England: Pearson Education Limited, 2014.

[22]. Kerlinger, F.N., "Foundations of behavioural research," Yogyakarta: Gadjah Mada University Press, 2014.

[23]. Cohen, L., Manion, L., Morrison, K. "Research methods in education,” London : RouledgeFalmer, 2005.

[24]. Khusainova, RM, Shilova, ZV, Curteva, O.V., "Selection of appropriate statistical methods for research results processing," International Electronic Journal of Mathematics Education, vol. 11(1), pp. 303-315, https://doi.org/10.12973/iser.2016.21030a, 2016.

[25]. Steinhorst, RK, and Keeler, C.M., "Developing material for introductory statistics courses from a conceptual, active learning viewpoint," Journal of Statistics Education, vol. 3(3), Rertieved from: https://doi.org/10.1080/10691898.1995.11910497, 1995

[26]. Pullinger, J., "Statistics making an impact," Journal of the Royal Statistical Society: Series A (Statistics in Society), vol. 176(4), pp. 819-840, 2013.

[27]. Tishkovskaya, S., and Lancaster, G.A., "Statistical education in the 21st century: A review of challenges, teaching innovations and strategies for reform," Journal of Statistics Education, vol. 20(2), Retrieved from: https://doi.org/10.1080/10691898.2012.11889641, 2012.

[28]. Sowey, E.R., "Letting students understand why statistics is worth studying," In Proceedings of ICOTS-7, Seventh International Conference on Teaching Statistics, 2016.

[29]. Herrmann, K.J, "The impact of cooperative learning on student engagement: Results from an intervention," Active learning in higher education, vol. 14(3), pp. 175-187, http://dx.doi.org/10.1177/1469787413498035, 2013.

[30]. Asrial, A., Syahrial, S., Kurniawan, D. A., Subandiyo, M., Amalina, N, "Exploring obstacles in language learning among prospective primary school teacher," International Journal of Evaluation and Research in Education (IJERE), vol. 8(2), pp. 249-254, Rterieved from: http://doi.org/10.11591/ijere.v8i2.16700, 2019.

[31]. Teimourtash, M., and Yazdanimoghaddam, M., "The Impact of fostering learner autonomy through implementing cooperative learning strategies on inferential reading comprehension ability of Iranian EFL learners," Iranian Journal of English for Academic Purposes, vol. 7(1), pp. 49-71, 2018.

[32]. Li, L.K., "A study of the attitude, self-efficacy, effort and academic achievement of city U students towards research methods and statistics," Discovery-SS Student E-Journal, vol. 1(54), pp.154-183, Retrieved from: https://pdfs.semanticscholar.org/b0a9/188bb5f66783c09624db8ca7b96922523ab5.pdf, 2012. 
[33]. Ramirez, C., Schau, C., Emmioglu, E., "The importance of attitudes in statistics education," Statistics Education Research Journal, vol. 11(2), Available: https://iase-web.org/documents/SERJ/SERJ11(2)_Ramirez.pdf, 2012.

[34]. Semin, F. K., "Competencies of principals in ensuring sustainable education: Teachers' views," International Journal of Evaluation and Research in Education (IJERE), vol. 8(2), pp. 201-212, Retrieved from: http://doi.org/10.11591/ijere.v8i2.18273, 2019.

[35]. Duda, HJ, Susilo, H., Newcombe, P., "Enhancing different ethnicity science process skills: Problem-based learning through practicum and authentic assessment," International Journal of Instruction, vol. 12(1), . https://eric.ed.gov/?id=EJ1201323, 2019.

[36]. Tosun, C., Taskesenligil, Y., "The effect of problem-based learning on undergraduate students' learning about solutions and their physical properties and scientific processing skills," Chem Educ. Res. Pract., vol. 14(1), pp.3650, Retrieved from: https://doi.org/10.1039/c2rp20060k, 2013.

[37]. Saputra, MD, Joyoatmojo, S., Wardani, DK, Sangka, KB., "Developing critical-thinking skills through the collaboration of jigsaw model with problem-based learning model," International Journal of Instruction, vol. 12(1), Retrieved from: https://eric.ed.gov/?id=EJ1201249, 2019.

[38]. Ersoy, E., "The effects of problem-based learning method in higher education on creative thinking," ProcediaSocial and Behavioral Sciences, vol. 116, pp. 3494-3498, Retrieved from: https://doi.org/10.1016/j.sbspro.2014.01.790, 2014.

[39]. Darmaji, D., Kurniawan, D. A., Irdianti, I, "Physics education students' science process skills," International Journal of Evaluation and Research in Education (IJERE), vol. 8(2), pp. 293-298, Retrieved from: http://doi.org/10.11591/ijere.v8i2.16401, 2019.

[40]. Gordon, S., "Understanding students' experiences of statistics in a service course," Statistics Education Research Journal, vol. 3(1), pp.40-59, 2004.

[41]. Leppink, J., Broers, JN, Imbos, T., "The effect of guidance in problem-based learning of statistic," The Journal of Experimental Education, pp. 292-294, Retrieved from: https://doi.org/10.1080/00220973.2013.813365, 2013.

[42]. Demirel, Dagyar, "Effects of problem-based learning on attitude: A meta analysis study," Eurasia Journal of Mathematics, Science \& Technology Education, vol. 12(8), pp. 2115-2137, Retrieved from: https://doi.org/10.12973/eurasia.2016.1293a, 2016.

[43]. Balapumi, R., Aitken, A, "Concepts and factors influencing independent learning in IS higher education," In ACIS 2012: Location, location, location: Proceedings of the 23rd Australasian Conference on Information Systems 2012 (pp. 1-10).

[44]. Barnes, L., "Evaluating independent learning development in a University Program," International Journal of Academy Research in Progressive Education and Development, vol. 2(1), pp. 152-159, 2013.

[45]. Tentama, F., Subarjo, S., Abdillah, M. H., "Motivation to learn and social support determine employability among vocational high school students," International Journal of Evaluation and Research in Education (IJERE), vol. 8(2), pp. 237-242, http://doi.org/10.11591/ijere.v8i2.18188, 2019.

[46]. Tuluk, G., and Kepeceoglu, I., "Pre-service teachers' web pedagogical content knowledge and online information searching strategies," International Journal of Evaluation and Research in Education (IJERE), ol. 8(2), pp. 229-236, Retrieved from: http://doi.org/10.11591/ijere.v8i2.18771, 2019.

[47]. Astalini, A., Kurniawan, D. A., Sulistiyo, U., Perdana. R., Susbiyanto, S., "E-Assessment Motivation in Physics Subjects for Senior High School," International Journal of Online and Biomedical Engineering (iJOE), vol.15(11), pp. 4-15, 2019. 